\title{
Analyses of Cystine in Human Hair: Its Level in Women's Hair of Former Times
}

\author{
Reiko YAMAmoto, ${ }^{1}$ Tsuguyoshi SuzUKI, ${ }^{2}$ and Hiraku TATEDA ${ }^{3}$ \\ ${ }^{1}$ Department of Public Health, Tohoku University School \\ of Medicine, Sendai 980, Japan \\ ${ }^{2}$ Department of Human Ecology, School of Medicine, \\ The University of Tokyo, Tokyo 113, Japan \\ ${ }^{3}$ Department of Pediatrics, Tohoku University School \\ of Medicine, Sendai 980, Japan
}

(Received December 24, 1980)

\begin{abstract}
Summary An appropriate procedure for analysis of cystine in the hair has been established, and this procedure was applied to the hair of Japanese women. The recovery of authentic cystine added to a hair sample was $85-90 \%$ in $6 \mathrm{~N} \mathrm{HCl}$ hydrolysis, and $96 \%$ in acid hydrolysis after performic acid oxidation. The 18-hr acid hydrolysis, but not 4-hr one, was sufficient to digest the hair. In colorimetry by using phosphotungstate, Brown's reagent gave a stable color development. The cystine content by amino acid autoanalysis was significantly correlated with that by the phosphotungstate colorimetry by the modified method of Kassel et al. or of Shinohara.

The cystine content in women's hair, which was collected from specimens of different individuals cut during the period from 1910s to 1980, indicated a wide variation ranging from 0.654 to $1.607 \mathrm{mmol}$ half-cystine per $\mathrm{g}$ of hair after washing with $0.5 \%$ sodium laurylsulfate.

Key Words human hair, cystine, amino acid autoanalysis, phosphotungstate colorimetry
\end{abstract}

The human hair grows fast and continuously, and consists of proteins. This enables the utilization of its growth, physical properties and amino acid composition as indices of malnutrition $(1-8)$. The hair proteins, usually denoted keratin as a whole, are split into two major components; sulfur-rich and sulfur-poor (9). Dietary intake of proteins that lack sulfur-containing amino acids would lead to the decreased formation of the sulfur-rich component of hair proteins. The content of cystine, a sulfur-containing amino acid, in the hair has been a target in studying the compositional change. Nevertheless, various studies of compositional change in

${ }^{1}$ 山本玲子, ${ }^{2}$ 鈴木継美, ${ }^{3}$ 館田 拓

Correspondence to Dr. R. Yamamoto at the following address: Department of Public Health, Tohoku University School of Medicine, Seiryo-cho 2-1, Sendai 980, Japan. 
malnutrition have not always given consistent results (8). The discrepancy could be due, in part, to inadequate analysis of cystine, because this amino acid is liable to be partly destroyed during the process of hydrolysis of hair (8) and the color produced for the previously utilized colorimetry $(10)$ is unstable.

We aimed to find suitable hydrolytic conditions for the analysis of cystine in the hair, to compare values obtained by the colorimetry used previously with that by amino acid autoanalysis, and to measure the cystine content by the established procedure in Japanese women's hair which had been cut previously or recently.

\section{MATERIALS AND METHODS}

The hair samples were obtained from Japanese women. The date of cut ranged from 1910s to 1980, and the hair cut had remained in each women's possession until collection. The samples after collection were stored in a dark place in the laboratory.

The finely cut hair samples were washed with $0.5 \%$ sodium lauryl sulphate (SDS) solution at $30^{\circ} \mathrm{C}$ for $30 \mathrm{~min}$, rinsed with distilled water, dried in warm air and weighed after cooling to the room temperature.

Tested procedures of hair digestion were as follows:

1) Hair samples were digested in $3 \mathrm{~N} \mathrm{HCl}$ solution with an autoclave at $120^{\circ} \mathrm{C}$ for $4 \mathrm{hr}$, and the digested mixture were filtered. An aliquot of filtrate was diluted with distilled water.

2) Hair samples were hydrolyzed with $6 \mathrm{~N} \mathrm{HCl}$ solution at $110^{\circ} \mathrm{C}$ for 4 or $18 \mathrm{hr}$ in air or in vacuo. The hydrolyzed sample was filtered. The filtrate was evaporated to dryness in vacuo with the aid of an aspirator at $30^{\circ} \mathrm{C}$, then suspended in distilled water, evaporated to dryness again, and dissolved in acid or alkali.

3) Hair samples were oxidized with performic acid by the procedure of Schram et al. (11), and thereafter the hydrolysis with hydrochloric acid mentioned in 2) was applied to the oxidized samples. Both cystine and cysteine in the hair are transformed by oxidation into cysteic acid that is stable under the acidic condition.

Determinations of cystine content were as follows:

1) The cystine content in the acid hydrolysate was colorimetrically measured by a modified method of Kassel and Brand (10) or Shinohara (12). In each case, Brown's reagent (13) (Daiich Kagaku Yakuhin, Japan) instead of Folin's reagent in the original method was used (the former gave a more stable color development in a preliminary experiment).

2) Amino acid analysis was carried out on an aliquot of the hydrolysate with a Hitachi High Speed Amino Acid Analyzer, Model 835.

\section{RESULTS}

Cystine contents determined by amino acid autoanalysis and by phosphotungstic acid methods are shown in Figs. 1 and 2. The values shown are mmol of cystine 


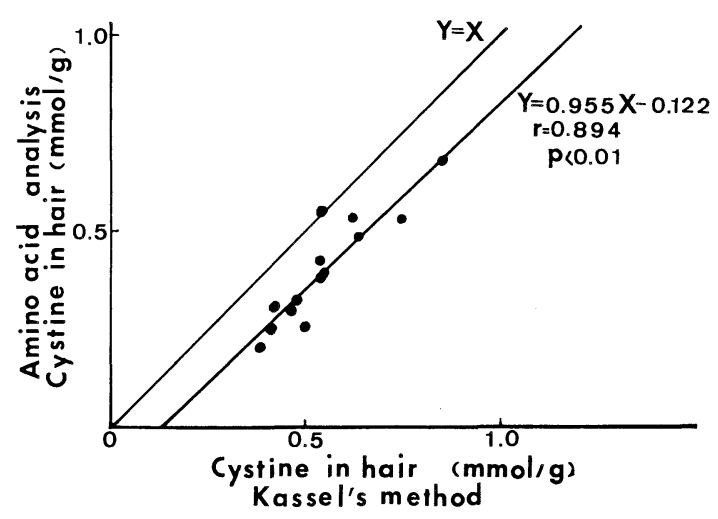

Fig. 1. Comparison between cystine content in hair by the modified method of Kassel and that by amino acid autoanalysis. Hair samples cut from 1910s to 1980 were hydrolyzed in $3 \mathrm{~N} \mathrm{HCl}$ at $120^{\circ} \mathrm{C}$ for $4 \mathrm{hr}$. Cystine content in hydrolysate was measured by the modified method of Kassel and Brand(10) or amino acid autoanalysis. The unit is expressed in terms of cystine (S-S) mmol/g hair in both methods.

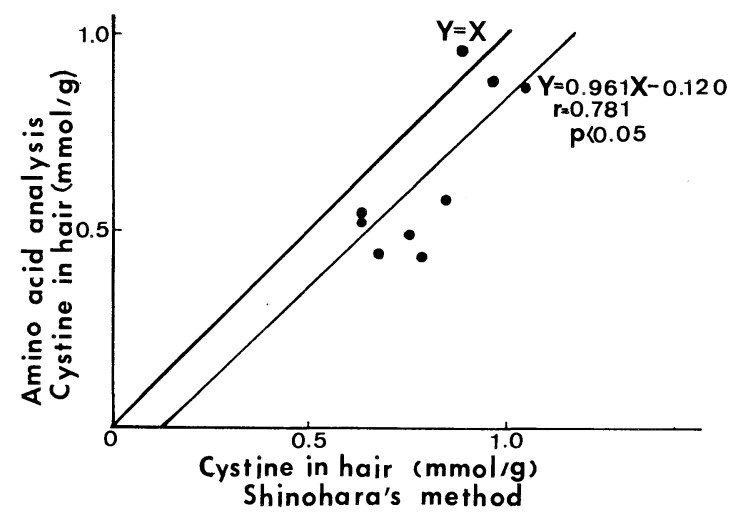

Fig. 2. Comparison between cystine content in hair by the modified method of Shinohara and that by amino acid autoanalysis. Hair samples were hydrolyzed in $6 \mathrm{~N} \mathrm{HCl}$ at $110^{\circ} \mathrm{C}$ for $18 \mathrm{hr}$. Cystine content in hydrolysate was determined by the modified method of Shinohara (12) or by amino acid autoanalysis. The unit is expressed in terms of cystine $(\mathrm{S}-\mathrm{S}) \mathrm{mmol} / \mathrm{g}$ hair in both methods.

(S-S) per g of hair. When hair samples were digested with $3 \mathrm{~N} \mathrm{HCl}$ at $120^{\circ} \mathrm{C}$ for $4 \mathrm{hr}$, cystine contents by the modified method of Kassel et al. correlated significantly with those by amino acid autoanalysis: The correlation coefficient is $0.894(p<0.01)$ (Fig. 1). Cystine contents by the modified Shinohara's method were, also, significantly but to a lesser extent correlated with those by amino acid autoanalysis $(r=0.781, p<0.05)$ when the hair was digested with $6 \mathrm{~N} \mathrm{HCl}$ at $110^{\circ} \mathrm{C}$ for $18 \mathrm{hr}$. Both colorimetric methods gave higher values than the amino acid autoanalysis.

Vol. 27, No. 5, 1981 
Table 1. Recovery of cystine after hydrolysis of hair.

\begin{tabular}{lccccc}
\hline $\begin{array}{c}\mathrm{HCl} \\
\text { hydrolysis }\end{array}$ & $\begin{array}{c}\text { Hair } \\
\text { used } \\
(\mathrm{mg})\end{array}$ & $\begin{array}{c}\text { Cystine } \\
\text { in hair } \\
\text { (mg in } \\
\text { hair used) }\end{array}$ & $\begin{array}{c}\text { Cystine } \\
\text { added } \\
(\mathrm{mg})\end{array}$ & $\begin{array}{c}\text { Cystine } \\
\text { found } \\
(\mathrm{mg})\end{array}$ & $\begin{array}{c}\text { Recovery } \\
\text { of cystine } \\
(\%)\end{array}$ \\
\hline $110^{\circ} \mathrm{C}, 4 \mathrm{hr}$ & 43.9 & 4.974 & 4.0 & 7.814 & 71.0 \\
in vacuo & 71.5 & 7.106 & 4.0 & 10.314 & 80.2 \\
$110^{\circ} \mathrm{C}, 18 \mathrm{hr}$ & 38.3 & 6.454 & 4.0 & 9.858 & 85.1 \\
in vacuo & 67.9 & 8.678 & 4.0 & 11.910 & 80.8 \\
$110^{\circ} \mathrm{C}, 18 \mathrm{hr}$ & 21.0 & 2.871 & 2.0 & 4.607 & 86.8 \\
in air & 18.2 & 2.337 & 2.0 & 4.281 & 97.2 \\
$110^{\circ} \mathrm{C}, 18 \mathrm{hr}$ & 22.4 & 2.966 & 1.0 & 3.911 & 94.5 \\
after PFA & 14.1 & 1.817 & 1.0 & 2.786 & 96.9 \\
\hline
\end{tabular}

PFA: Performic acid oxidation. Cystine was determined by amino acid autoanalysis.

Table 2. Effect of washing of hair with sodium laurylsulfate (SDS) on cystine measurement.

\begin{tabular}{cccc}
\hline $\begin{array}{c}\text { Sample } \\
\text { no. }\end{array}$ & $\begin{array}{l}\text { Washing with } \\
\text { distilled water }\end{array}$ & \multicolumn{2}{c}{$\begin{array}{c}\text { Washing with } \\
0.5 \%\end{array}$} \\
\hline & & SDS \\
1 & 1.08 & & $(\%)$ \\
2 & 0.85 & 0.56 & $(51.9)$ \\
3 & 0.98 & 0.49 & $(57.6)$ \\
Mean & 0.97 & 0.53 & $(54.1)$ \\
SD & 0.115 & 0.53 & $(54.5)$ \\
& & 0.035 & $(2.9)$ \\
\hline
\end{tabular}

Hair sample was cut and collected in 1975. Cystine (S-S) in hair was measured by the modified method of Kassel et al. after the $\mathrm{HCl}$ hydrolysis at $120^{\circ} \mathrm{C}$ for $4 \mathrm{hr}$.

Recovery of authentic cystine added to the hair sample was $85-90 \%$ in $6 \mathrm{~N} \mathrm{HCl}$ hydrolysis and $96 \%$ in the acid hydrolysis after performic acid oxidation. There was no difference between the recovery of cystine in vacuo and in air at 4 and $18 \mathrm{hr}$ in acid hydrolysis (Table 1), but the 4-hr hydrolysis gave smaller values than the 18 -hr hydrolysis after correcting cystine content by the recovery. This means that the 4-hr hydrolysis is inadequate to release cystine and cysteine.

Washing of a hair sample which was cut and collected in 1975 with $0.5 \%$ SDS at $30^{\circ} \mathrm{C}$ for $30 \mathrm{~min}$ reduced the cystine content in the hair by $55 \%$ when compared with the values from the same hair sample washed with distilled water, but not SDS (Table 2).

The content of cystine in the hair of Japanese women showed a wide variation (Table 3). The hair samples were obtained from different individuals, and the dates of cut also varied. 


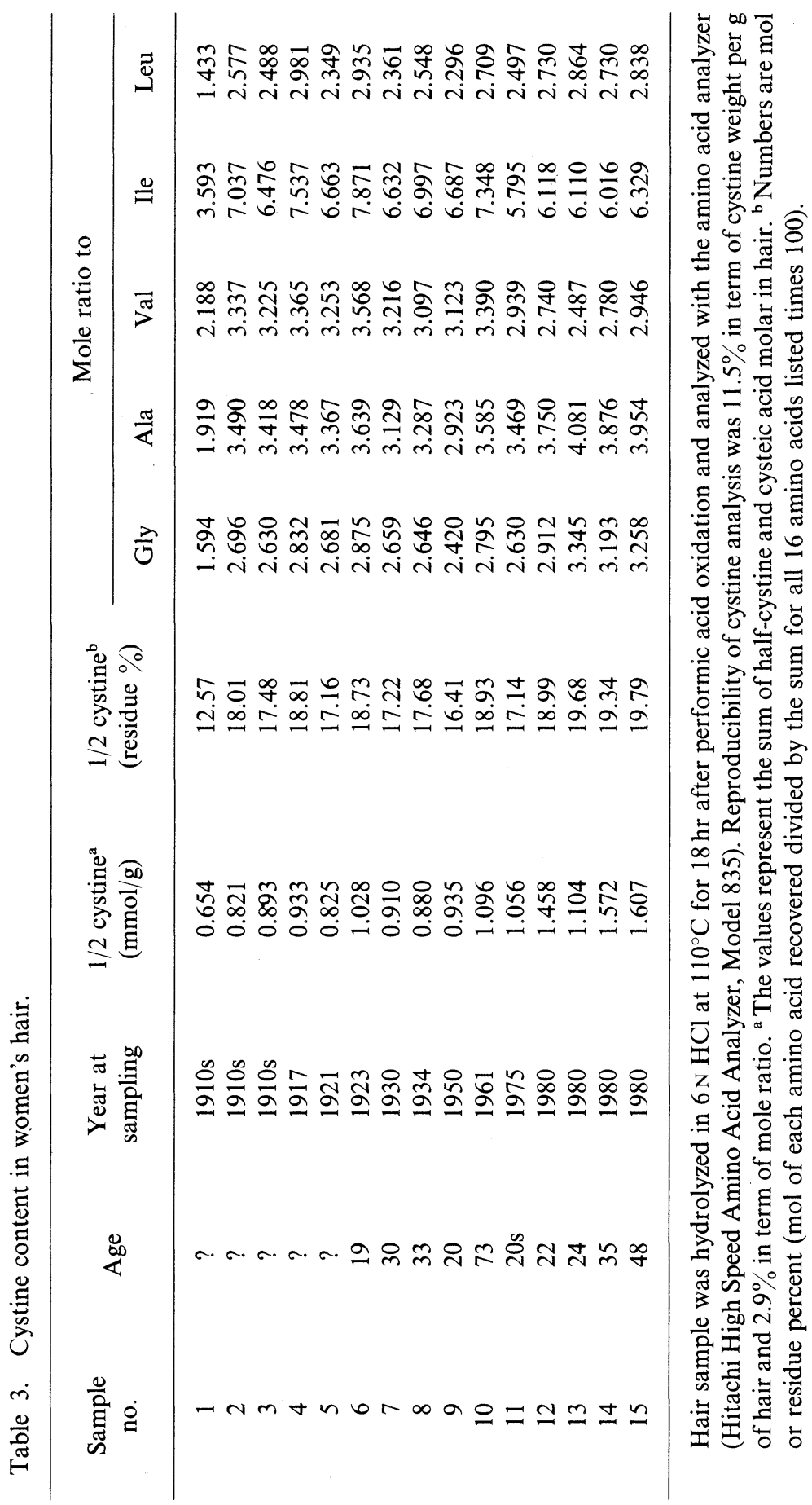

Vol. 27, No. 5, 1981 
Residential places of women at the cut of hair were in a rural district of Nagano prefecture for samples cut before 1950, and the city of Tokyo or Sendai for those cut more recently. The procedure used for analysis was (1) washing of hair with $0.5 \%$ SDS, (2) acid hydrolysis with $6 \mathrm{~N} \mathrm{HCl}$ for $18 \mathrm{hr}$ at $110^{\circ} \mathrm{C}$ after performic acid oxidation, and (3) amino acid autoanalysis. The values obtained ranged from 0.654 to $1.607 \mathrm{mmol}$ half-cystine per $\mathrm{g}$ of hair.

\section{DISCUSSION}

Regarding the hydrolytic condition, we obtained evidence that hydrolysis in vacuo was not necessary, because the loss during hydrolysis in air could be fully corrected by the recovery rate of authentic cystine added to sample. Especially, after performic acid oxidation, the recovery of cystine in air was close to that in vacuo. The 18-hr acid hydrolysis is considered to be sufficient to release cystine and cysteine; however, the 4-hr hydrolysis gave a much lower release, when compared with the value reported by Miyazawa et al.(14) and Robbins and Kelly (15) who carried out the hydrolysis with $6 \mathrm{~N} \mathrm{HCl}$ refluxed for $44-48 \mathrm{hr}$.

Koyanagi et al. $(2,3)$ employed the phosphotungstate method after hydrolysis of hair samples in $3 \mathrm{~N} \mathrm{HCl}$ at $120^{\circ} \mathrm{C}$ for $4 \mathrm{hr}$ and concluded that malnourished children were significantly different from normal children in hair cystine content. Since the 4-hr hydrolysis is insufficient to obtain adequate release of cystine and cysteine, the reported values of cystine were dubious, but the difference between the malnourished and normal cases is still meaningful. Though the data were not shown in the text, we observed a good correlation between the cystine value measured under the same condition as that of Koyanagi et al. and that as cysteic acid by the amino acid analysis after hydrolysis with $6 \mathrm{~N} \mathrm{HCl}$ for $18 \mathrm{hr}$ at $110^{\circ} \mathrm{C}(r=0.903$, $p<0.01$ ).

Regarding the measurement of cystine, (1) the phosphotungstate method gave higher values than the amino acid autoanalysis, (2) cystine values obtained, however, showed a good correlation with those by autoanalysis, and (3) the precision of determination by the modified method of Kassel et al. and by amino acid autoanalysis was 4.2 and $2.6 \%$ (as coefficient of variation), respectively (data not shown in the text). From these results, the phosphotungstate method is useful with the limitation of inevitable rectification of the value obtained.

Another problem is the contamination of hair. The effect of washing with SDS suggests that the hair is contaminated with cosmetics such as shampoo containing cystine or proteins.

To assess nutritional status by the content of cystine in the hair, the relationship between the amount of cystine in the hair and the protein balance should be studied further. The present data concerning the cystine content in Japanese women are too meagre to make a conclusive statement. However, the low value of cystine content in the hair which was cut in the period prior to World War II is contrasted with the high value in hair cut after World War II. The national 
statistics on food supply tell us that the supply of food of animal origin was very poor in the prewar period and it started to increase after World War II (16). This encourages us to do further studies on the content of cystine in hair.

\section{REFERENCES}

1) Close, J. (1958): Les modifications chimiques et morphologiques des cheveux, accompagnant le kwashiorkor. Ann. Soc. Belg. Med. Trop., 38, 95-104.

2) Koyanagi, T., and Takanohashi, T. (1961): Cystine content of hair of children as influenced by vitamin A and animal protein in diet. Nature, 192, 457-458.

3) Koyanagi, T., Hareyama, S., and Takanohashi, T. (1965): Effect of supplementation of vitamin, phosphorus, methionine or skim milk on the cystine content of hair, dark adaptation, creatine, creatinine excretion and growth of undernourished children. Tohoku J. Exp. Med., 85, 108-114.

4) Bigwood, E. J., and Robazza, F. (1965): Amino acid and sulphur content of hair in normal African natives and in kwashiorkor. Voeding, 16, 251-256.

5) Hartman, D. R., Fougere, W., and King, K. W. (1966): Diameter and amino acid changes in hair of negro children with protein-calorie malnutrition. Proc. Soc. Exp. Biol. Med., 123, 542-544.

6) Bradfield, R. (1973): Hair tissue in the diagnosis of marasmus and kwashiorkor. J. Am. Med. Women's Assoc., 28, 393-394.

7) Bradfield, R. (1973): Protein-calorie malnutrition diagnosis by hair tissue. Environ. Child Health, 370-375.

8) Friedman, M., and Orraca-Tetteh, R. (1978): Hair as an index of protein malnutrition. in Nutritional Improvement of Food and Feed Proteins, ed. by Friedman, M., Plenum Press, New York, pp. 131-154.

9) Fraser, R. D. B., MacRae, T. P., and Rogers, G. E. (1972): Keratins, C. C. Thomas, Springfield, pp. 3-6.

10) Kassel, B., and Brand, E. (1938): The photometric determination of cystine, cysteine, ascorbic acid, and related compounds with phosphotungstic acid. J. Biol. Chem., 125, 115-129.

11) Schram, E., Moore, S., and Bigwood, E. (1954): Chromatographic determination of cystine as cysteic acid. Biochem. J., 57, 33-37.

12) Shinohara, K. (1935): The determination of thiol and disulfide compounds, with special reference to cysteine and cystine. J. Biol. Chem., 112, 671-682.

13) Brown, H. (1945): The determination of uric acid in human blood. J. Biol. Chem., 158, 601-608.

14) Miyazawa, F., Tamura, T., and Nozaki, F. (1976): Alteration of amino acid composition and keratinolysis of hair due to chemical damage. in Biology and Disease of Hair, ed. by Toda, K., Ishibashi, Y., Hori, Y., and Morikawa, F., University of Tokyo Press, Tokyo, Japan, pp. 659-667.

15) Robbins, C. R., and Kelly, C. (1969): Amino acid analysis of cosmetically altered hair. J. Soc. Cosm. Chem., 20, 555-564.

16) Department of Investigation, Agriculture and Forestry Minister's Secretariat (1976): The Statistical Data of Food Supply and Demand (in Japanese), The Statistics Association of Agriculture and Forestry, Tokyo, Japan, pp. 3-245. 